\section{US federal agencies add extra steps for handling GM plants}

$F_{b}$ deral officials took steps in August to bolster regulatory safeguards governing the testing and development of genetically modified (GM) plant species and also recommended a new scheme to guard against inadvertent exports of GM crops into markets where such products are not sought.

In the first of these developments, officials in the White House Office of Science and Technology Policy (OSTP; Washington, DC) are proposing to update field testing requirements of biotechnology-derived food and feed crop plants and to establish early food safety assessments for new proteins produced by such plants. These proposals were prompted, in part, by recommendations put forth in a National Research Council (NRC; Washington, DC) report earlier this year, "Environmental Effects of Transgenic Plants" (Nat. Biotechnol. 20, 323, 2002).

The use of biotechnology-derived crops in the United States has increased markedly over the past decade, OSTP officials point out. In 1994, approximately 7,000 acres were planted under 593 US Department of Agriculture (USDA; Washington, DC) field-test authorizations, compared with 57,000 acres under 1,117 authorizations in 2001. The first biotechnology-derived crops were commercialized in 1996, and in 2001, approximately 88 million acres were planted in the United States and 130 million acres were planted worldwide. This continuing expansion puts pressure on the regulatory agencies that review new GM products at different stages of their development.

"As the number and diversity of field tests increase, the likelihood that cross-pollination due to pollen drift from field tests to commercial fields and commingling of seeds produced under field tests with commercial seeds or grain may also increase," OSTP officials note, echoing comments that appear in the 2002 NRC report. "The measures proposed ... are aimed at preventing low levels of biotechnology-derived genes and gene products from being found in commercial seed, commodities, and processed food and feed until appropriate safety standards can be met."

The tougher standards are to be applied separately by the three federal agencies principally involved in regulating GM plants and foods and feeds derived from them, namely the Food and Drug Administration (FDA; Rockville, MD), the
Environmental Protection Agency (EPA; Washington, DC), and the USDA. Perhaps the most important new principle for officials at those agencies to follow is that: "If a trait or protein presents an unacceptable risk or the risks cannot be determined adequately, field test confinement requirements would be rigorous to restrict outcrossing and comingling of seed and the occurrence at any level of biotechnologyderived genes and gene products from these field tests would be prohibited in commercial seed, commodities, and processed food and feed."

Agency-specific requirements will vary. The FDA, for instance, plans to develop a list for its website of all proteins, potentially produced in GM plants, that the agency considers acceptable or unacceptable in terms of toxicity and allergenicity. The EPA is to develop new guidelines for dealing with field trials and addressing safety issues involving consumption of plants with plant-incorporated protectants, the currently preferred term for describing pesticides and the genes needed for making them. And the USDA is being asked to amend criteria for allowing regulated materials into commercial seed and commodities, if they "pose no unacceptable environmental risk," according to the report. Although the USDA has already "strengthened field-testing controls for permits on those bioengineered traits that are not intended for commodity uses, such as pharmaceuticals, veterinary biologics, or certain industrial products," officials may elect to impose even stricter "confinement procedures, performance standards, and monitoring/auditing practices" if deemed necessary.

"BIO supports the Bush administration's decision, consistent with ongoing advancements in the technology, to further enhance the federal regulatory process that has provided oversight for biotechnology-derived products since 1986 designed to ensure food and environmental safety," says Michael J. Phillips, executive director of food and agriculture of the Biotechnology Industry Organization (BIO; Washington, DC). "BIO members will comply with this added layer of oversight and consider it to be a mandatory requirement in the development of crops improved through the use of biotechnology. For consumers, this enhancement adds yet another layer of assurance to the existing regulatory review of agricultural crops intended for both food and feed."

However, consumer-representation groups and environmental organizations are criticizing the OSTP proposals, particularly those that pertain to the testing of plants engineered to produce pharmaceutical products. For instance, rather than focusing on containment procedures, critics such as Joseph Mendelson of the Center for Food Safety (Washington, DC) are calling for a blanket moratorium on any testing of such plants.

Meanwhile, consumers outside the United States who insist on GM-free products stand a better chance of fulfilling their demands with US exports, according to proposals put forward in August by officials from two additional USDA agencies, the Agricultural Marketing Service (AMS) and the Grain Inspection, Packers and Stockyards Administration (GIPSA). They are planning to inaugurate a voluntary GM product-testing program to expedite the export of GM-free crops, including to the emergent non-biotech niche market.

Early this year, GIPSA began offering a voluntary "Proficiency Program" for organizations testing for biotechnology-derived grains and oilseeds to help improve the reliability of testing. If demand warrants, AMS will provide a similar service for seed, fruit, and vegetable markets. Additional auditbased tracking systems also might be made available to provide a reasonable assurance that claims regarding seed quality and genetic purity are truthful.

Ironically, these efforts are getting under way while USDA Secretary Ann Veneman has been stepping up efforts to win favor for US biotech exports, particularly in China, where officials have been considering stiff barriers against such products. By the conclusion of a visit to China and Japan late in July, Veneman appeared confident that, although still not resolved, the outlook for US exports of GM soybeans to China is bright. "We're continuing to expand our discussions on agriculture biotechnology," she says. "Not just as it relates to the soybean issues and the regulations but a broader cooperative relationship because both the United States and China are doing a tremendous amount of research in promising new technologies.... But we also want to work cooperatively together on the way that these kinds of new technologies will be regulated. So, we've agreed with the Chinese authorities in the various ministries to have a joint working group to look together at some of these issues."

Jeffrey L. Fox, Washington, DC 